\title{
US to rule on use of science in regulations
}

Washington. The Clinton administration has dropped its outright opposition to risk assessment legislation proposed by Republican members of Congress, and has agreed to cooperate on laws which will revolutionize the use of science in setting rules in spheres as diverse as water pollution, occupational health and air transport.

The change in position was signalled last week by senior officials of the Environment Protection Agency (EPA), as they absorbed new Republican proposals for risk assessment legislation. The proposals - published as part of HR9, the Job Creation and Wage Enhancement Act of 1995 - are considerably more moderate than measures promised last September in the Contract with America, the Republican election manifesto.

The proposed legislation will shape the interface between science and government regulation, dictating the steps which government agencies must take to

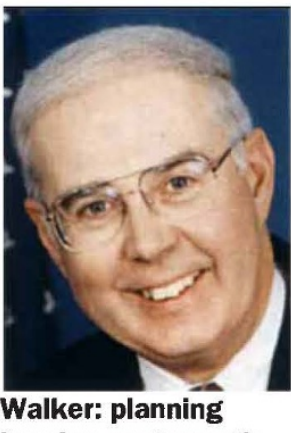
hearing next month. evaluate scientific evidence before they impose regulations.

Lynn Goldman, assistant administrator for pesticides and toxic substances at the EPA — the agency most directly affected by the proposals - says that in the past, the agency had preferred to handle the complexities of risk assessment internally. "Now we've decided we can support legislation," she says.

The section of the bill dealing with risk assessment had been modified to meet concerns voiced recently by Carol Browner, the EPA administrator. For example, it will not subject each stage in the risk assessment process to judicial review, nor will it allow a single member of a peer review panel to veto the process.

But Goldman says that other parts of HR9, such as 'paperwork' provisions that would allow the Office of Management and Budget to block any regulation it didn't like, whatever its scientific justification, are still opposed by the agency.

Environmentalists have long opposed risk assessment legislation, fearing that it will give too much power to panels of scientists whose views will be coloured by their direct and indirect links to industry. But industrialists are strongly in favour, believing such legislation will hold back over-zealous regulation.

Jim Wilson, a policy analyst at chemicals manufacturer Monsanto, says that "the re-write has taken out most of the bones of contention" in the Contract with America

proposal, including its provisions for a cumbersome peer review process. He argues that the proposed law will help the public by forcing agencies to explain publicly the scientific basis of regulations.

But Adam Finkel, a senior fellow at the Green Center for the Study of Science and Society at the University of Texas, Dallas, who works with environmental groups on risk assessment, complains that the bill asks scientists "to be precise in a particular way", and says this could lead to bad public policy.

According to Finkel, opposition to the proposed legislation is likely to focus on its basic pretext - that a group of scientists, reflecting opposing viewpoints, should be able to agree on a "best estimate" quantifying the risk, for example, of a particular pollutant causing cancer. "The issue is whether the models are right or wrong," he says.

\section{NASA plans for shuttle replacement}

Washington. The US National Aeronautics and Space Administration (NASA) last week asked aerospace companies to submit ideas for a new reusable space vehicle to replace the space shuttle in the next century. NASA and industry will jointly develop technology for the new vehicle over the next four years, and will decide by 1999 whether to go ahead with production.

The reusable launch vehicle (RLV) was a key part of the national space transportation plan signed by President Bill Clinton last August. But the White House delayed NASA's call for proposals by about two months while it tried to assure itself that the shrinking space agency could afford a major new programme.

Even last week, there were financial uncertainties. NASA's press release did its best to avoid a specific dollar commitment for the project. It described "the potential level of government funding estimated to be available through [fiscal year] 1999" to be "approximately $\$ 650$ million".

Cost estimates for building an operational RLV vary from a few billion dollars to more than $\$ 10$ billion. NASA and the Defense Department will spend about $\$ 100$ million this year on the technology development programme. By 1996 it hopes to have enough information to decide whether to build and demonstrate a test vehicle, currently known as the X-33.

NASA officials say they are looking for a revolutionary vehicle that can reduce space transportation costs dramatically. Rather than dictating the design of the RLV, the agency has merely set performance goals. It wants the vehicle to operate autonomously, with no pilot on board, to be able to deliver 25,000 pounds of cargo to the proposed international space station and to launch
Republicans have compromised on a number of fronts. For example, the legislation, will only affect regulations costing more than of $\$ 25$ million, rather than $\$ 1$ million as originally proposed, and full peer review will only be applied to rules costing more than $\$ 100$ million.

Under the Contract with America, the House is committed to voting on a bill by April. The Science committee, chaired by Robert Walker (Republican, Pennsylvania), will hold hearings early next month, and move quickly to mark up the risk assessment section of the bill. Protests about indecent haste will draw short shrift. "The process is never perfect, but this issue has been fairly vented," says one committee staff member. "I'm sitting here reading three, single-space pages listing hearings we've held on it since 1982."

Colin Macilwain again a week after landing.

NASA is also soliciting designs for a smaller test vehicle, called the X-34, able to carry 1,000 to 2,000 pounds into orbit. It plans to spend approximately $\$ 70$ million up to the end of the decade in developing this concept, including orbital tests scheduled to take place by mid-1998. Orbital Sciences Corporation, which builds the small Pegasus rocket, is a favourite to win this contract.

NASA has previously developed plans for space planes, but it has never reached the point of building a prototype. This time it wants to do business differently. Industry partners will be expected to match NASA's investment, rather than building a vehicle under contract to the government.

Some companies are worried at the prospect of sinking money into a government project that could be cancelled at the whim of Congress. But others see it as a potentially lucrative project that they cannot afford to ignore. Boeing and McDonnell Douglas, for example, have already announced plans to team up for an X-33 design, and Lockheed has at least one concept waiting in the wings.

One question to be answered before any RLV gets final approval is whether there is sufficient market demand. NASA wants the vehicle to carry cargo to the space station, and eventually to replace its ageing shuttle fleet. After that, the agency hopes the RLV's lower flight costs will open up new markets.

Both Congress and the administration will be watching the RLV programme closely, and it will be an important test of how well the NASA administrator, Dan Goldin, has reformed his agency. Critics have claimed in the past that NASA bureaucracy stifles any truly 'revolutionary' and cost-conscious approach to vehicle development.

Tony Reichhardt 